\title{
PENTINGNYA RISET KEBIJAKAN DALAM PEMBUATAN KEBIJAKAN PUBLIK UNGGUL DI INDONESIA
}

\author{
Anugerah Yuka Asmara
}

Pusat Penelitian Perkembangan Iptek, a.yuka.asmara@gmail.com

\begin{abstract}
Abstrak
Kebijakan publik di Indonesia cenderung kurang terimplementasi dengan baik, meskipun proses pembuatan kebijakan publik dilakukan sesuai prosedur. Salah satu faktornya ialah hasil-hasil riset, terutama riset sosial atau kebijakan belum menjadi pertimbangan utama bagi para pembuat kebijakan. Mereka cenderung menggunakan pertimbangan intuisi dan pengalaman pribadi daripada menggunakan hasil-hasil riset dalam menentukan suatu kebijakan publik baru. Parahnya, tidak sedikit dari mereka yang hanya melandaskan kepentingan politik dan ekonomi di dalam setiap pembuatan kebijakan demi kepentingan elit tertentu, bukan masyarakat secara keseluruhan. Padahal, kebijakan publik yang berdasar riset atau bukti dapat membentuk kebijakan publik unggul yaitu kebijakan yang dapat memecahkan masalah terkini, tidak membuat masalah lain lebih besar, serta memberi harapan bagi masyarakat. Tujuan kebijakan publik unggul agar citra dan kepercayaan pemerintah yang saat ini menurun dapat terangkat di mata publik Indonesia dan dunia.
\end{abstract}

Kata Kunci: Pembuatan kebijakan, Kebijakan publik unggul, Riset dan hasilnya

\begin{abstract}
A public policy in Indonesia tends to be implemented insufficiently good, although a public policy making process has been undertaken sequentially. One of factors is the neglected research results, particularly a social or policy research has not become yet as a main consideration for the policy makers. They tend using an intuition consideration and a personal experience rather than using the research results in determining a new public policy. Unfortunately, majority of policy makers use a political and economic consideration in each of stages of policy making process to fulfill the various elite interests, not for public as a whole. Important to be known that a evidence-based policy can create a sound public policy. It is a policy to resolve the recent problems, to minimize the mistakes/failures, and giving a bright wish for people in the future. The aim of this sound public policy is to hoist the image and trust of Indonesian Government in the perspective of Indonesian and foreign people currently.
\end{abstract}

Keywords: Public policy making, Sound public policy, Research and evidence

\section{PENDAHULUAN}

Kebijakan pemerintah dapat berbentuk intervensi baik di bidang ekonomi, sosial-kemanusiaan, pertanianperikanan-peternakan, kesehatan, ilmu pengetahuan dan teknologi, serta pertahanan-keamanan. Wahab (2008) mengungkapkan bahwa "sebagai keluaran kebijakan itu dilihat dari apa yang senyatanya dihasilkan atau diberikan oleh pemerintah". Mengacu pada batasan di atas, kebijakan merupakan produk keluaran dari pemerintah yang dampaknya dapat dirasakan oleh masyarakat baik secara langsung maupun tidak langsung yang itu tertulis ataupun tidak tertulis.

Kenyataan di Indonesia, mayoritas kebijakan yang dibuat oleh pemerintah belum berdasar riset (Sudharto, 2011). Gubernur Sumatera Barat (Prayitno, 2011) mengungkapkan bahwa "dalam melahirkan berbagai kebijakan, para pemimpin lebih banyak mengandalkan hasil pertimbangan semata dan tidak berdasarkan hasil penelitian (riset). Sekalipun ada, hasil riset tidak terimplementasi secara terarah. Akibatnya kebijakan yang diambil sama sekali tidak menyentuh kesejahteraan rakyat".

Policy makers di Indonesia perlu memprioritaskan riset kebijakan sebagai landasan dasar bagi pembuatan kebijakan publik. Sekdaprov Jambi, Syahrasaddin (2011) menyatakan bahwa "kebijakan yang dibuat pemerintah harus berdasarkan riset ilmu pengetahuan agar tidak sia-sia tanpa implementasi". Riset harus diberikan tempat pada proses pembuatan kebijakan, utamanya sebagai input bagi policy makers. Bagaimanapun, penelitian akan memberikan angin segar bagi pemecahan masalah, terlebih lagi pada permasalahan sosial yang memiliki pergerakan yang amat dinamis.

Sehubungan dengan latar belakang di atas, maka pertanyaan penelitian ini ialah.

1. Bagaimana model pembuatan kebijakan publik di Indonesia saat ini ?

2. Bagaimana hasil-hasil riset kebijakan berpengaruh terhadap kebijakan di beberapa negara? 
3. Bagaimana riset kebijakan sebagai salah satu faktor yang dapat membentuk kebijakan publik unggul di Indonesia?

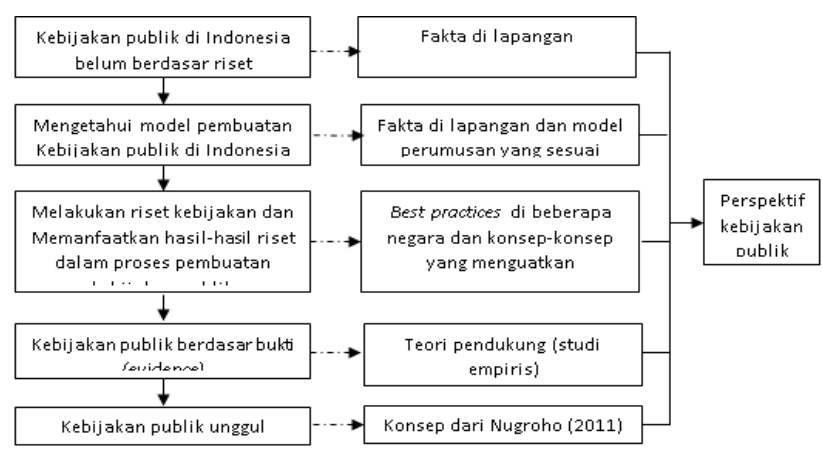

Gambar 1. Kerangka Pikir Penulisan

\section{METODE}

Jenis penelitian ini ialah studi pustaka (desk research) yang dilakukan selama bulan Desember 2011 hingga Mei 2012. Jenis penelitian ini ialah kualitatif dengan menghasilkan data deskriptif. Bogdan dan Taylor dalam Moleong (2000) menyatakan bahwa "metode kualitatif sebagai prosedur penelitian yang menghasilkan data deskriptif berupa kata-kata tertulis atau lisan dari orang-orang dan perilaku yang dapat diamati”. Penelitian ini menggunakan beberapa dokumen seperti buku, jurnal ilmiah, artikel ilmiah dan populer sebagai referensi utama dalam memperoleh data utama dan menganalisis data tersebut.

Penelitian ini menggunakan analisis data interaktif. Miles dan Huberman (1992) memberikan 4 (empat) tahap analisis data yaitu :

a. Pengumpulan data, yaitu mengumpulkan semua data.

b. Reduksi data, merupakan proses pemilihan dan penyortiran data.

c. Penyajian data, peneliti dapat melihat data yang diperoleh secara utuh.

d. Penarikan kesimpulan dilakukan secara induktif.

HASIL DAN PEMBAHASAN

A. Model Pembuatan Kebijakan Publik di Indonesia

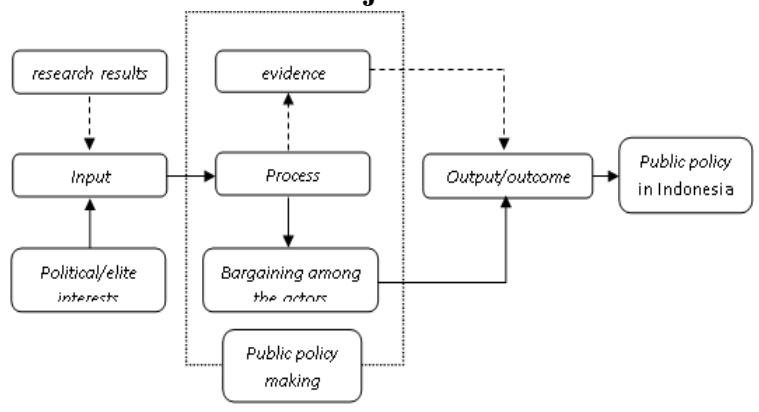

Gambar 2. Model Sederhana Pembuatan Kebijakan Publik di Indonesia
Gambar di atas menjelaskan bahwa sebagian besar proses pembuatan kebijakan publik di Indonesia belum menggunakan riset sebagai pertimbangan utama. "Selama ini kebijakan-kebijakan yang dikeluarkan masih belum berdasarkan penelitian" (Royani, 2011). "Masih banyak pejabat kurang menggunakan riset dalam mengambil keputusan penting, sehingga sering keliru dan banyak yang merugikan masyarakat. Pejabat yang belum menggunakan hasil riset untuk mengambil kebijakan, dikarenakan telah menjadi kultur yang terlalu lama dipandang oleh pejabat tersebut, sehingga setiap kebijakan yang diambil hanya berdasarkan pemikirannya saja" (Jamil, 2011).

Beberapa kebijakan yang tidak berdasar riset telah menyebabkan negative impact yang amat besar bagi masyarakat. Sebagaimana yang dicontohkan Qodari (2006) yaitu "Dua contoh kebijakan makro yang tidak berdasar riset, yaitu kenaikan harga BBM dan juga pemberian Bantuan Langsung Tunai (BLT) yang menyebabkan terjadi konflik hampir di tiap daerah ketika mengimplementasikan kebijakan tersebut'.Contoh penerapan kebijakan menaikkan harga BBM yang tanpa didahului riset matang menimbulkan berbagai pertentangan di kalangan pakar di bidangnya.

"Ketika pemerintah menaikkan harga BBM dengan alasan terbebaninya APBN oleh subsidi BBM, penolakan argumentasi ini banyak terjadi. Publik sebenarnya meletakkan masalah utamanya adalah mengapa negara Indonesia yang kaya sumber daya alam di bidang gas, minyak dan hasil tambang lainnya, harus melakukan impor dari luar negeri. Kwik Kian Gie (mantan Menko Perekonomian di jaman Presiden Gus Dur dan kepala Bappenas di era Presiden Megawati) dengan tegas menolak argumen pemerintah" (Zamroni, 2008:5).

Contoh lain kebijakan tidak berdasar riset ialah kebijakan pendidikan. Wakil Menteri Pendidikan dan Kebudayaan Bidang Pendidikan Musliar Kasim (2011) mengakui bahwa "berbagai kebijakan pendidikan belum berdasar pada hasil riset dan analisis mendalam. Riset pendidikan selama ini hanya bersifat reaktif dan solusi masalah jangka pendek, pemerintah tidak memiliki strategi kebijakan pendidikan jangka panjang”. Sebagaimana yang diungkap anggota Komisi X (Pendidikan, Olahraga dan Kebudayaan), Rohmani (2011) menguatkan pernyataan Kasim tersebut.

"Sejak adanya dana bantuan operasional sekolah (BOS) pemerintah kerapkali mengubah tata cara penyaluran dana BOS itu. Seharusnya pemerintah dalam membuat setiap kebijakan harus mempertimbangkan dampak negatifnya, dan juga harus mempertimbangkan kondisi sosiologis dan tata 
aturan perundang-undangan. Kebijakan pemerintah belum berdasarkan hasil riset. Bukan kajian yang matang, ini yang membuat pendidikan kita tidak maju-maju. Dari dulu, begitu-begitu saja. Bisa jadi, malah mundur. Karena pemangku kebijakan tidak serius bekerja (Republika, 19 Agustus 2011).

Beberapa contoh di atas menguatkan bahwa riset terutama riset kebijakan (policy research) belum menyentuh policy makers sebagai bahan input suatu kebijakan yang sedang atau akan dirumuskan. Akibatnya output/outcome kebijakan publik tidak mengandung bukti/fakta (evidence) yang seharusnya didapat dari riset kebijakan.

Sebaliknya, policy makers di Indonesia lebih memilih pertimbangan-pertimbangan elitis dalam merumuskan/membuat kebijakan publik. Mereka lebih memilih bagaimana untuk memadukan atau menampung kepentingan-kepentingan elit yang beraneka ragam (elit interests) baik untuk manfaat ekonomi maupun politik. Akibatnya kebijakan publik yang dihasilkan didasarkan pada proses tawar-menawar (bargaining process) diantara berbagai kepentingan elit, bukan menampung kepentingan masyarakat secara keseluruhan (public interests) di level menengah-bawah atau yang tidak terlibat dalam proses pembuatan kebijakan publik.

"Kebanyakan kebijakan publik Indonesia berisikan hasil "tawar-menawar" atau "kesepakatan" elite politik (dan kepentingannya) daripada benar-benar mencerminkan kebijakan yang pro-kepentingan publik" (Nugroho, 2011). Pernyataan ini menguatkan bahwa model pembuatan kebijakan publik di Indonesia tendesi ke arah model elit-massa. Susanto (2000) menyatakan bahwa :

"Model elit-massa memandang administrasi (pemerintah) bukan dalam kapasitas sebagai servant of the people, tetapi sebagai kelompok kecil yang telah mapan (established). Kebijakan pemerintah merupakan perwujudan keinginan-keinginan utama tentang nilai-nilai golongan elite berkuasa yang mengalir dari atas, yaitu dari golongan elite ke golongan massa. Massa sama sekali tidak berperan dalam rnerumuskan apalagi ikut memutuskan kebijakan pemerintah, sebab massa dianggap pasif, apatis, dan miskin informasi”.

Contohnya, setelah reformasi ada lembaga survei yang didirikan dengan tujuan sebagian besar pada kepentingan elit-elit politik di Indonesia, yaitu meraih suara (polling) dari para pendukung suatu partai politik. Sejalan dengan hal di atas, Crewe and Young (2000) mengungkapkan :
"Elit-elit mungkin dipengaruhi oleh faktor-faktor politik dan kelembagaan yang memliki ruang untuk manuver yang lebih luas dari kelompok-kelompok yang terpinggirkan. Kesempatan-kesempatan dibuat bagi anggota-anggota dari jaringan kebijakan untuk mengambil keuntungan dari ruang ataupun jendela kebijakan (policy spaces or windows). Sementara itu, beberapa aktor atau organisasi yang kurang kredibilitas akan diabaikan.”

Sebagaimana yang disinggung di atas, model elit pembuatan kebijakan publik di Indonesia menjadi salah faktor penghambat mengapa hasil-hasil riset, terlebih lagi riset kebijakan belum mendapat tempat di dalam pemikiran policy makers. Di sini evidence tidak menjadi "a main priority" sebagai input pembuatan kebijakan publik.

\section{B. Best Practices Kebijakan Publik Berdasar Riset di Beberapa Negara}

Berbagai hasil riset di bidang sosial termasuk riset kebijakan telah memberikan pengaruh yang signifikan terhadap pembuatan kebijakan publik di beberapa negara.

\section{Di Kanada}

Pemerintah di beberapa negara mengakui pentingnya peran penelitian dalam pengambilan kebijakan. Misalnya, di tahun 1996, inisiatif penelitian kebijakan dibuat oleh Pemerintah Federal untuk mengembangkan suatu strategi penelitian bagi Kanada guna mempersiapkan tantangan terhadap kebijakan publik yang kompleks yang kemungkinan besar akan dihadapi oleh Pemerintah Kanada beberapa tahun akan datang. Itu bertujuan untuk membangun fondasi keahlian dan pengetahuan yang kokoh dengan berdasar pada keputusan kebijakan yang kuat dan kredibel dengan berlandaskan pada keahlian dan pengetahuan, serta berkontribusi untuk membentuk komunitas penelitian Kanada yang kuat dan vital (Policy Research Initiative dalam Dukeshire and Thurlow, 2002).

Contoh di Kanada tersebut memberi gambaran bahwa pengetahuan dengan kesiapan para ahli di bidangnya menjadi landasan utama dalam setiap kebijakan yang akan dibuat oleh policy makers di negara tersebut. Alasan Pemerintah Kanada ini karena kebutuhan di masa depan akan menjadi lebih kompleks daripada kebutuhan saat ini. Karena itu Pemerintah Kanada membentuk komunitas penelitian yang kuat agar riset benar-benar sebagai masukan (input) pada proses pembuatan kebijakan publik. 


\section{Di Inggris}

Di Inggris, kebijakan publik berdasar riset terkait dengan kebijakan penggunaan kompor hemat bakan bakar yang dapat mengurangi jumlah penebangan pohon di Inggris dan belahan dunia lain. Suatu analisis energi membuat kesimpulan sederhana di tahun 1980-an, berdasar pada pengamatan penggunaan bahan bakar dan penebangan hutan, bahwa penggunaan kompor yang sangat efisien dapat menyelamatkan pohon-pohon. Berdasar hasil riset tersebut digunakan untuk membenarkan keputusan memangkas pendanaan. Para donatur merujuk kepada : a) pengamatan bahwa penduduk pedesaan tidak memotong pohon untuk konsumsi bahan bakar kayu, dipublikasikan di dalam sebuah tulisan buku yang pendek dan sederhana oleh Jurnalis Inggris, b) beberapa bukti anekdok dan selektif bahwa sebagian besar program kompor lainnya memiliki catatan kurang baik, c) studi pemakaian waktu yang menunjukkan bahwa ketika para kaum perempuan menghemat waktu, itu tidak akan membedakan daya pendapatan (Crewe and Young, 2000).

Contoh di Inggris tersebut membuktikan bahwa suatu riset dapat mempengaruhi pengambilan kebijakan dalam hal penggunaan kompor hemat bahan bakar. Tujuan dari kebijakan tersebut ialah agar pohon-pohon yang tumbuh di Inggris dan beberapa negara lain dapat dipertahankan/diselamatkan hidupnya guna menjaga keseimbangan ekosistem dunia. Ditambah lagi, penggunaan kompor hemat bakar berdasar hasil riset tidak akan mengurangi daya pendapatan sehari-hari terutama dari golongan perempuan.

\section{Di Uruguay}

Studi di Uruguay menunjukkan bahwa hasil-hasil kumulatif sejumlah studi penelitian sosial digunakan dalam kebijakan pengembangan dan perbaikan kontrol program penyakit Chagas dan kaki-mulut. Sementara itu, studi penelitian kesehatan tersebut dapat memiliki kemungkinan dampak kebijakan sektor lain di luar kesehatan (Chunharas, 2000).

Bagi Pemerintah Uruguay, hasil riset digunakan sebagai masukan pada kebijakan di bidang kesehatan yaitu pengendalian penyakit Chagas dan kaki-mulut. Tidak sampai di situ, riset di bidang kesehatan ternyata memiliki dampak di bidang-bidang non-kesehatan lainnya.

\section{Di Vietnam}

Di Vietnam, guna mendukung pembuatan kebijakan melalui proyek penelitian berdasar bukti ilmiah yang telah dilaksanakan dari tahun 2008 hingga pertengahan tahun 2011 dibentuk Akademi Ilmu Pengetahuan Sosial Vietnam. Pendanaan dibiayai oleh program PBB dengan tiga penguatan kinerja yaitu : a) penguatan kapasitas manajemen penelitian, b) menjalankan penelitian menggunakan paradigma pengembangan manusia, dan c) mendukung para peneliti dalam menghubungkan penelitian mereka dengan proses kebijakan. Akademi Ilmu Pengetahuan Sosial Vietnam memiliki 30 kelembagaan dengan 1500 peneliti. Sebuah penilaian kebutuhan dilakukan pada Juni 2009 menunjukkan bahwa : sejak tahun 2005 permintaan pada akademi untuk penelitian kebijakan meningkat. Permintaan ini meningkat lebih besar ketika "jendela kebijakan” (policy window) terbuka karena pentingnya kegiatan kebijakan di Vietnam (Pellini and Serrat, 2010).

Dengan kelembagaan penelitian yang dimiliki saat ini, Vietnam sebagai salah satu negara di Asia Tenggara mampu mendongkrak "pasar penelitian" (research market) yang selangkah lebih maju dari negara-negara tetangga di kawasan Asia Tenggara. Peningkatan permintaan penelitian terhadap kebijakan publik telah mengubah pandangan policy makers di Vietnam sejak tahun 2005. Riset telah menjadi pertimbangan utama bagi policy makers di negara ini. Terbukti dengan digunakannya jasa Akademi Ilmu Pengetahuan Sosial di Vietnam baik oleh para politisi partai politik maupun oleh pejabat tingkat nasional di Vietnam dalam merumuskan kebijakan

\section{Riset Kebijakan Dapat Membentuk Kebijakan Publik Unggul (Sound Public Policy)}

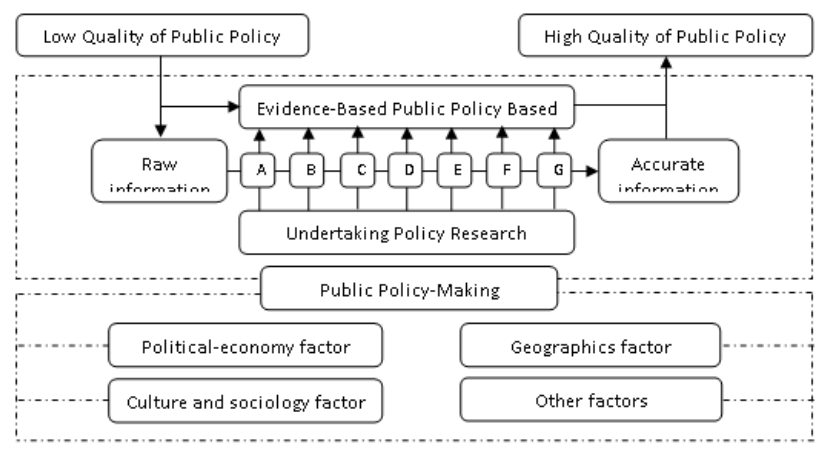

Gambar 3. Evidence Dapat Meningkatkan Kualitas Kebijakan Publik

Keterangan :

7 Unsur pembuatan kebijakan publik oleh Thurlow and Dukeshire (2002)

$\begin{array}{ll}\text { A } & \text { : Case Studies } \\ \text { B } & \text { : Field Experiments } \\ \text { C } & \text { : Cost Benefit Analysis } \\ \text { D } & \text { : Secondary Analysis } \\ \text { E } & \text { : Qualitative Methods } \\ \text { F } & \text { : Focused Review of Existing Research } \\ \text { G } & \text { : Surveys }\end{array}$


Berdasar gambar di atas, sebuah kebijakan publik yang baik ialah kebijakan publik yang berkualitas tinggi (high quality). Suatu kebijakan publik memang tidak langsung memiliki kualitas tinggi (high quality) tetapi berawal dari kebijakan publik dengan tingkat kualitas rendah (low quality) maupun lebih rendah (lower quality) dengan melaui tahapan proses pembuatan kebijakan publik yang benar.

Tahap pembuatan kebijakan publik merupakan proses kompleks yang dipengaruhi oleh berbagai faktor yang ada. Dror dalam Wahab (2008) mengungkapkan bahwa "public policy making merupakan suatu proses yang sangat kompleks dan dinamis terdiri dari beberapa unsur yang satu sama lain kontribusinya berbeda-beda terhadap pembuatan kebijakan publik tersebut". Faktorfaktor tersebut ialah kepentingan politik, ekonomi, budaya/perilaku (sosiologis) masyarakat yang menjadi target groups dari kebijakan tersebut, keadaan geografis, dan faktor-faktor lain yang saling berkaitan dan mempengaruhi isi suatu kebijakan.

Aktualnya, meskipun dipengaruhi oleh berbagai faktor di dalam proses pembuatan kebijakan publik, policy makers pada umumnya akan menitikberatkan pada satu faktor yang mempengaruhi isi suatu kebijakan. Misalnya karena fakor ekonomi lebih kuat daripada faktor sosiologis masyarakat dengan alasan peningkatan kesejahteraan masyarakat, maka policy makers akan lebih menetapkan konten suatu kebijakan dengan mayoritas atau bahkan sepenuhnya dengan tujuan ekonomi. Padahal dalam suatu pembuatan kebijakan publik, policy makers harus dapat mengadopsi dan merangkul berbagai kepentingan yang ada baik kepentingan policy makers maupun kepentingan masyarakat yang menjadi kelompok sasaran (target groups) suatu kebijakan. Nugroho (2011:110) menyatakan "kebijakan publik adalah keputusan otoritas negara yang bertujuan mengatur kehidupan bersama."

Agar suatu kebijakan publik tidak bias dengan hanya pengaruh satu fakor dan mendeskritkan faktor lain, sudah seharusnya suatu kebijakan publik yang dibuat didasarkan pada bukti (evidence). Bukti harus didapatkan secara komprehensif agar informasi tidak diperoleh sepotong atau justru menjadi informasi yang tidak akurat. Untuk itu, informasi mentah (raw information) yang didapat diolah lagi agar informasi tesebut menjadi informasi yang akurat (accurate information). Informasi yang akurat ialah informasi yang memiliki kebenaran tinggi saat digunakan dalam proses pembuatan kebijakan publik. Di ilmu-ilmu sosial, informasi yang dianggap benar hanya relatif, yaitu keakuratannya secara absolut tidak sampai $100 \%$ sebagaimana di ilmu-ilmu eksakta. Hal ini dikarenakan memang karakteristik ilmu-ilmu sosial yang cenderung mengkaji studi-studi yang pergerakannya cukup dinamis di tengah kehidupan masyarakat yang amat kompleks.

Informasi akurat untuk kebijakan publik dapat diperoleh dengan meminjam tujuh metode umum penelitian yang relevan dalam pembuatan kebijakan publik oleh Thurlow and Dukeshire (2002) yaitu 1) case studies, 2) field experiments, 3) cost benefit analysis, 4) secondary analysis, 5) qualitative methods, 6) focused review of existing research, 7) surveys.

1) Studi kasus (case studies) dilakukan dengan melibatkan rekaman dan analisis pengalaman aktual dari sebuah organisasi atau komunitas di sekitar isu-isu tertentu. Studi kasus dapat mengidentifikasi perilaku dan variabelnya dan sering memberikan pemahaman lebih lengkap akan suatu keadaan yang kompleks.

2) Eksperimen lapangan (field experiments) berguna untuk mengumpulkan bukti-bukti (evidence) terkait dengan dampak perubahan kebijakan utama yang potensial saat implementasinya dan untuk monitoring serta evaluasi dampak perubahan kebijakan setelah implementasinya.

3) Analisis biaya manfaat (cost benefit analysis) melibatkan seperangkat metode dimana peneliti membandingkan biaya dan manfaat untuk masyarakat terhadap opsi alternatif kebijakan. Analisis ini dapat memperhitungkan isu-isu moneter/ekonomi, sosial, lingkungan dan isu-isu kebijakan lain.

4) Analisis sekunder (secondary analysis) menggunakan data yang sudah ada sebagaimana halnya dokumen/arsip. Misalnya data statistik yang dapat menggambarkan keadaan suatu permasalahan yang kompleks melalui grafik, sehingga terlihat sederhana. Meskipun beberapa isu perilaku sosial yang kompleks tidak dapat didekati dengan model statistik

5) Metode kualitatif (qualitative methods) menggunakan data non numerik dan umumnya melalui pengumpulan dan analisis data naratif. Metode ini terutama untuk memperoleh kekayaan informasi secara mendalam terkait isu-isu atau masalah-masalah dan memberikan solusi yang spesifik pula.

6) Tinjauan penelitian yang telah ada secara terfokus (Focuse review of existing research) yaitu melalui me-review tulisan-tulisan dan temuan-temuan penelitian yang telah ada dan relevan untuk menjawab isu-isu terkini. Misalnya saja berbagai artikel yang telah dipublikasikan, sumber-sumber diskusi dengan ahli, stakehokders, pengalaman para peneliti, dan sebagainya. 
7) Survei (survey) digunakan untuk mengumpulkan data tentang isu-isu atau persoalan-persoalan dan penyebabnya. Survei kemungkinan melibatkan wawancara personal atau kuesioner yang dilakukan sekali atau beberapa periode. Teknik yang dipakai ialah dengan melakukan polling, yaitu teknik pengukuran opini dari publik yang dihitung dengan rumus statistik.

Ketujuh tipe metode tersebut bukan berarti harus digunakan secara bersamaan, melainkan dipilih metode mana yang appropriate untuk mengkaji persoalanpersoalan yang terjadi. "Tipe penelitian dan metode yang digunakan untuk mengumpulkan dan menyajikan data itu dapat mempengaruhi bagaimana informasi dapat diinterpretasikan dan digunakan" (Thurlow and Dukeshire, 2002). Pengolahan informasi mentah menjadi informasi akurat tersebut akan menghasilkan sebuah bukti (evidence) yang siap pakai (ready to be used) oleh policy makers.

Evidence tersebut tidak langsung diperoleh saat kita melakukan riset kebijakan (policy research), melainkan terlebih dulu melakukan kegiatan penelitian dasar di bidang ilmu sosial. Menguatkan hal ini Royyani (2011) mengemukakan bahwa "riset dasar dan lanjutan di bidang sosial bisa menjadi dasar bagi penentu kebijakan dalam menyusun kebijakan, yang sesuai dengan harapan masyarakat". Selain itu, riset yang telah dilakukan harus didorong terus-menerus agar terjadi kesinambungan antara riset terdahulu dengan saat ini. Curtain (2009) menegaskan: "kebijakan publik yang baik (good public policy) didasarkan pada pembelajaran dari pengalaman. Pembuatan kebijakan perlu kontinuitas, proses pembelajaran yang tidak hanya sebuah rangkaian mati, yang inisiatifnya terisolasi. Ini butuh penggunaan bukti (evidence) dan penelitian terkait masalah yang diatasi". Penelitian yang dimaksud di sini ialah penelitian yang memberikan kontribusi kepada public policy-making process.

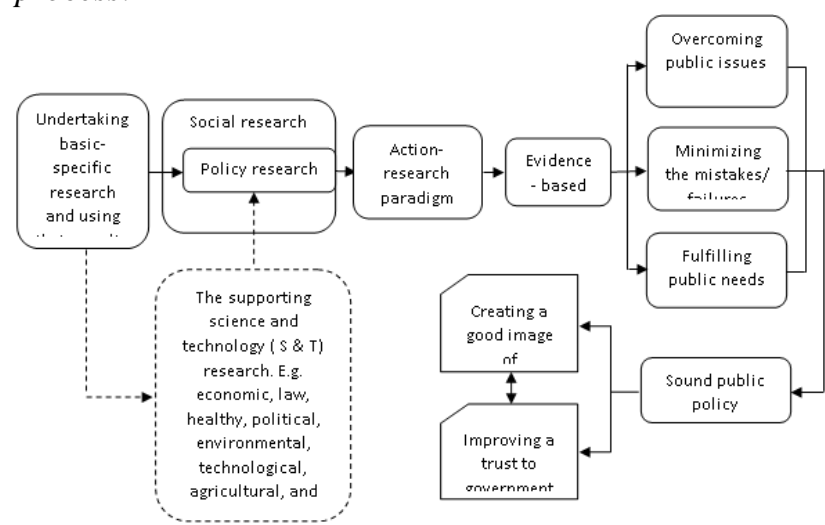

Gambar 4. Riset Kebijakan dapat membentuk Kebijakan Publik Unggul (Sound Public Policy)
Pengertian undertaking basic-specific research di sini tidak hanya sebatas pada melakukan kegiatan riset (riset baru) saat kebijakan publik akan dirumuskan, tetapi juga policy makers dapat memanfaatkan hasil-hasil penelitian yang sudah ada dan sesuai, sebagai input untuk perumusan kebijakan publik. Menguatkan hal ini, Stine (2009) menyatakan "scientific and technical knowledge and guidance influences many of today's public policies”.

Penelitian kebijakan merupakan bagian dari penelitian ilmu sosial. "Penelitian kebijakan dapat dipikirkan sebagai penelitian sosial terapan karena penelitian kebijakan memiliki fokus utama yang sama dengan penelitian sosial terapan, yaitu dalam pemecahan masalah sosial praktis" (Meyer and Greenwood dalam Nugroho 2011). Riset kebijakan tentunya bukan disiplin ilmu yang berdiri sendiri. Sebagaimana yang dinyatakan Nugroho (2011) "karena kebijakan publik bersifat multidisplin, pengetahuan yang diperlukan juga multidisplin". Oleh karena itu penelitian kebijakan perlu pendekatan mutidisiplin ilmu pengetahuan lain seperti ilmu ekonomi, politik, lingkungan, kesehatan, pertanian, teknologi, hukum, dan lainnya.

"Menurut para pakar ilmu kebijakan, pembuatan kebijakan publik haruslah didasarkan atas prinsip-prinsip ilmiah dan bagi setiap masalah tersedia suatu cara pemecahan yang rasional yang dapat dicapai dengan memanfaatkan analisis kebijakan" (Wahab, 2008:158). Riset kebijakan akan menghasilkan temuan-temuan penelitian yang berdasar bukti (evidence-based), bukan berdasar pertimbangan/perkiraan policy makers semata maupun hasil kajian satu disiplin ilmu saja

Salah satu fitur dari paradigma research to action ialah adanya kolaborasi antara disiplin-disiplin akademis dan diantara sektor serta pendekatan inklusif untuk penelitian dimana ide dan sudut pandang dari komunitas-masyarakat dibawa bersama dengan perspektif akademis dan pemerintah. Pergeseran paradigma ini telah memberikan beberapa alasan termasuk lebih menyebutnya penelitian yang bertanggungjawab, muncul permintaan untuk pendekatan yang berbasis bukti (evidence) untuk perencanaan dan pembuatan keputusan (Frankish et al and Green et al dalam Dukeshire and Thurlow, 2002).

Setelah evidence dihasilkan, maka dampak selanjutnya akan muncul options terhadap masalah yang hendak dipecahkan. Paling tidak ada 3 (tiga) manfaat yang didapat melalui evidence-based public policy-making ini antara lain: 1) mengatasi persoalan publik saat ini (overcoming public issues), 2) meminimalisir kesalahan/kegagalan akan suatu pilihan kebijakan (minimizing the mistakes/failures), 3) memenuhi kebutuhan publik (fulfilling public needs). 
Pertama, evidence yang dihasilkan melalui riset kebijakan memiliki tujuan utama menyelesaikan permasalahan-permasalahan publik terkini (overcoming public issues). Majchrzak dalam Dukeshire and Thurlow (2002) menyatakan "penelitian kebijakan adalah unik, ia fokus untuk memberi rekomendasi tindakan (action-oriented recommendations) atas masalah-masalah sosial". Menguatkan hal itu Rasiyo (2009) mengatakan bahwa "penyelesaian masalah yang berkaitan dengan kebijakan publik hendaknya didasarkan pada hasil penelitian yang dapat dipertanggungjawabkan".

Kedua, evidence dari riset kebijakan juga memberi preferensi untuk menentukan alternatif terbaik dari sekian alternatif yang ada. Ini akan meminimalisir kesalahan/kegagalan (minimizing the mistakes/failures) suatu kebijakan saat diimplementasikan. Majchrzak dalam Nugroho (2011) mengatakan bahwa "upaya riset kebijakan mulai dengan masalah sosial.....berkembang melalui sebuah proses penelitian dimana alternatif aksi kebijakan untuk meminimalisir masalah yang berkembang dan mengkomunikasikan beberapa alternatif yang ada dengan policy makers".

Ketiga, riset kebijakan dengan evidence yang dihasilkan akan berupaya untuk memenuhi kebutuhan publik (fulfilling public needs). Pestieau (2003:5) menyatakan "penelitian kebijakan dapat menginformasikan kepada policy makers dan publik mengenai biaya pilihan-pilihan yang berbeda dan diharapkan serta berkontribusi menyesuaikan pilihanpilihan dengan kemungkinan yang ada”. Apa yang diungkapkan oleh Pestieau tersebut menyingkap bahwas riset kebijakan dapat memberi kepuasan kepada publik dengan berbagai pilihan solusi masalah yang ditawarkan sesuai dengan resources yang ada di lingkungan tersebut.

Ketiga manfaat dari riset kebijakan di atas cenderung sesuai (matching) dengan konsep kebijakan yang dikemukakan oleh Nugoroho (2011) yang ia sebut sebagai kebijakan publik unggul. Disini penulis akan menggunakan istilah sound public policy untuk dipertukarkan dengan istilah kebijakan publik unggul tersebut.

Dikaitkan dengan konsep Nugroho maka manfaat pertama riset kebijakan yaitu overcoming public issues sama dengan "cerdas" yaitu memecahkan masalah pada inti permasalahannya. Disini memang kebijakan publik menurut Wibawa (2011) adalah "keputusan suatu sistem politik untuk mengelola suatu masalah atau memenuhi suatu kepentingan........" Jadi salah satu syarat kebijakan publik unggul ialah dapat menyelesaikan masalah dimana itu dapat dilakukan melalui riset kebijakan.

Manfaat kedua ialah minimizing the mistakes/failures sama dengan "bijaksana" yaitu, kebijakan yang dibuat sebisa mungkin tidak menghasilkan masalah baru yang lebih besar daripada masalah yang dipecahkan. Mengingat tantangan kebijakan publik akan selalu dinamis menjawab tantangan saat ini dan masa depan yang unpredictable. Oleh karena itu kebijakan yang dibuat harus bisa mengantisipasi dampak negatif lain apa yang didapat dan seberapa besar pengaruh dampak itu saat kebijakan diimplementasikan (put into practice). Pola ini hampir sama dengan penerapan manajemen resiko (risk management) kebijakan yang diungkapkan oleh Nugroho (2011) bahwa "kebijakan publik yang unggul adalah kebijakan publik yang dibuat dengan memasukkan unsur resiko di saat ini dan masa depan, yang berarti memasukkan unsur manajemen resiko di dalamnya". Bahkan seharusnya pembuatan kebijakan harus dapat menekan biaya secara ekonomi. Wahab (2008) mengungkapkan bahwa "pembuatan kebijakan publik dimaksudkan untuk mencapai tingkat manfaat (benefit) yang maksimum, yaitu bahwa kepentingan umum yang terapai itu diperoleh dengan korban/biaya (cost) yang lebih sedikit".

Manfaat ketiga ialah fulfilling public needs sama dengan "memberikan harapan" dimana jika kebutuhan masyarakat (public needs) terpenuhi oleh pemerintah berarti masyarakat dapat berharap kepada pemerintah bahwa mereka dapat menjalani hari-hari ke depan yang semakin baik. Kebijakan publik harus mengandung harapan bagi masyarakat secara umum dan konstituen-nya. Dukeshire and Thurlow (2002) menyatakan bahwa penelitian dapat bermain peran utama dalam proses pembuatan kebijakan dan ada tekanan lebih besar pada penelitian kebijakan untuk membantu menginformasikan keputusan kebijakan masa depan.

Kebijakan publik unggul ini memang suatu tipe "ideal" yang diharapkan setiap pemerintah dimanapun. Pasalnya pemerintah ingin program-programnya diakui oleh masyarakat dengan semakin meningkatnya kepercayaan (trust) publik kepada pemerintah. Nugroho (2011:56) menguatkan bahwa "keberhasilan kebijakan publik mendorong upaya memperkuat kepercayaan sosial yang selanjutnya akan menjadi nilai dan norma budaya yang mengikat secara kuat komunitas bangsa tersebut".

Selain trust yang dapat dibangun melalui sound public policy ini maka secara simultan citra baik (good image) pemerintah juga akan terbentuk di dalam persepsi masyarakat mengingat saat ini citra 
Pemerintah Indonesia di hadapan publik menurun. Sebagaimana Menteri Dalam Negeri Gamawan Fauzi (2012) ungkapkan bahwa "terjadi penurunan tingkat kepercayaan kepada PNS saat ini”.selanjutnya, Adiyanto (2011) menegaskan bahwa "pemerintah harus mempertimbangkan dampak kebijakan untuk mendapat rasa kepercayaan dari publiknya".

Mengacu pada pengertian Dye (1981) bahwa "apapun yang dilakukan atau tidak dilakukan pemerintah itu dianggap sebagai kebijakan publik", maka apapun yang dilakukan maupun tidak dilakukan oleh pemerintah akan membuahkan sesuatu hal yang baik dan dapat dipercaya. Hal ini kemudian dengan sendirinya akan menumbuhkan trust pada pemerintah yang berasal dari masyarakat secara umum termasuk konstituen-nya.

Kebijakan publik yang tidak dilandasi oleh riset tidak hanya akan berakibat pada kurang responnya dalam menjawab kebutuhan masyarakat di lapangan, akan tetapi juga dapat melemahkan peran strategis pemerintah di hadapan rakyatnya. Qodari (2006) mengungkapkan ;

"Sebuah riset dinilai sangat penting dalam mengambil sebuah kebijakan publik, karena kebijakan publik bersentuhan langsung dengan kehidupan masyarakat. Jika rakyat senang terhadap kebijakan dari pemerintah tersebut, maka pemerintah akan sukses. Akan tetapi bila rakyat tidak suka dan marah, maka tunggu saja, pemerintahan akan dijatuhkan oleh rakyat. Riset sangat penting sebelum kebijakan publik diambil oleh pejabat setingkat kepala daerah seperti gubernur atau bupati, atau pimpinan di tingkat kepala dinas (kadis) agar tidak terjadi konflik dengan masyarakat.

\section{Contoh Riset Telah Digunakan Sebagai Bahan} Pembuatan Kebijakan Publik di Provinsi Sumatera

\section{Barat}

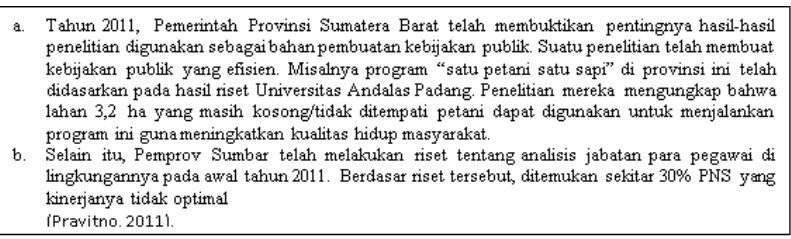

Proses pembentukan menuju kebijakan publik unggul (sound public policy) tidaklah sesederhana sebagaimana yang dikonsepkan dalam Gambar 4 di atas. Meskipun sound public policy diperoleh melalui policy research sebagaimana yang diungkapkan oleh Qodari (2006) bahwa penelitian ilmiah harus menjadi faktor penentu pengambil kebijakan, akan tetapi, Crewe and Young (2000:10) mengungkap hal yang agak berbeda bahwa "setiap sound policies yang berdasar pada penelitian yang akurat, itu pun dapat terjadi distorsi dalam prakteknya ....”. Ini disebabkan karakteristik ilmu sosial yang mengkaji isu-isu yang bergerak cepat dan silih berganti dengan kondisi lingkungan yang berbeda di tiap tempat.

Alasan Crewe and Young di atas bukan berarti mematahkan semangat dilakukannya riset kebijakan guna menghasilkan kebijakan publik unggul. Melanjutkan pernyataan Crewe and Young (2000) "...... tetapi sound policies adalah bagian dari strategi yang pantas/dapat diandalkan (sensible)". Pernyataan ini sekaligus membenarkan pernyataan Wolfgang Pauli yang dikutip dalam Pellini dan Serrat (2010) bahwa "That theory is worthless. It isn't even wrong." Kedua pernyataan tersebut memberi kekuatan pemahaman baik dalam konsep maupun praktek bahwa kebijakan publik yang unggul dapat dilakukan melalui riset kebijakan.

Satu hal terpenting lagi ialah riset kebijakan tidak serta berjalan linear begitu saja guna mencapai evidence yang mendorong terbentuknya sound public policies. Meskipun evidence akan memberikan suatu kebenaran tingkat scientific dan practice, itu tetap akan dipengaruhi oleh aktor-aktor kepentingan lain dalam publc policy-making process, namun dengan tingkat yang lebih kecil. Komposisi evidence sendiri akan menyeimbangakan (equal) atau paling tidak meminimalisir pengaruh-pengaruh dari elit yang tidak penting bagi suatu kebijakan

\section{PENUTUP}

\section{Simpulan}

1. Umumnya riset-riset ilmu-ilmu sosial terutama riset kebijakan belum mendapat "privelege" di para policy makers di Indonesia. Hal ini berdampak pada pengambilan kebijakan yang terkesan sembarangan karena tidak berdasar evidence.

2. Berdasar Best practices dari keempat negara (Kanada, Inggris, Uruguay, dan Vietnam), memberikan gambaran betapa pentingnya riset dalam mendukung pembuatan suatu kebijakan di masing-masing negara tersebut.

3. Kebijakan publik sudah seharusnya didasarkan pada hasil-hasil riset (evidence). Riset merupakan salah satu sarana (means) penghubung antara kebutuhan masyarakat di lapangan saat itu juga dengan para policy makers. Melalui pemanfaatan riset, diharapkan kebijakan publik yang dihasillkan dapat memenuhi tiga hal yaitu: 1) memecahkan masalah terkini, 2) tidak membuat 
masalah lain lebih besar, 3) serta memberi harapan bagi masyarakat.

\section{Saran}

1. Membekali aparat pemerintah baik sebagai policy maker maupun policy implementator dengan pemahaman akan pentingnya riset dalam pengambilan kebijakan. Bentuknya seperti sosialisasi, pelatihan/workshop, atau kursus singkat.

2. Memberi dukungan bagi peneliti sosial/kebijakan untuk melakukan riset mendalam baik melalui peningkatan dana, infrastruktur penunjang, dan insentif yang layak.

3. Mendesiminasikan hasil-hasil riset sosial/kebijakan ke masyarakat umum, terutama mereka yang direncanakan menjadi target groups of policy.

4. Meningkatkan kapasitas kelembagaan riset dan pengembangan baik di tingkat pemerintah pusat maupun daerah melalui peningkatan kualitas dan kuantitas sumber daya peneliti, infrastruktur penunjang kegiatan litbang, dan dukungan legalitas penuh dari pimpinan kelembagaan.

5. Menjalin kerjasama dalam memorandum of understanding (MoU) dengan berbagai pihak terkait seperti lembaga litbang swasta (dalam negeri dan asing), perguruan tinggi swasta/negeri, perusahaan domestik atau asing terkait, serta berbagai pemerintah daerah di Indonesia maupun kelembagaan pemerintah asing.

\section{DAFTAR PUSTAKA}

Adiyanto, Wiwid. 2011. Upaya Biro Humas Sekretariat Daerah Provinsi Jawa Tengah Dalam Menjalin Hubungan Baik Dengan Media. Tugas Akhir Program Studi Hubungan Masyarakat, Jurusan Ilmu Komunikasi, Fisipol Universitas Diponegoro, Semarang.

Arikunto, Suharsimi. 2002. Prosedur Penelitian, Suatu Pendekatan Praktek. Jakarta : PT Rineka Cipta.

Chunharas, Somsak. 2000. Lessons in Research to Action and Policy:Case studies from seven countries. The Council on Health Research for Development. A COHRED issues paper.

Crewe, Emma and Young, John. 2000. Bridging Research and Policy : Context, Evidence, and Links. Overseas Development Institute. Working Paper 173.

Curtain, Richard. 2000. Good Public Policy Making: How Australia Fares. Journal of Policy Analysis and Reform. Volume 8, Number 1, 2000, pages 33 46.

Dukeshire, Steven and Thurlow, Jennifer. 2002.Understanding the Link Between Research and Policy. Rural Communities Impacting Policy.

Dye, Thomas R. 1978. Understanding Public Policy. N.J Englewood Cliffs : Prentice Hall, Inc.

Fauzi, Gamawan. 2012. Mendagri: Kepercayaan terhadap PNS Turun. Diakses dari http://www.depdagri.go.id.

Geru, Hetty Antje. 2012. Implementasi Kebijakan Penanggulangan Perdagangan Wanita. Jurnal Ilmu Administrasi Negara (JIANA) Volume 12 Nomool: 19-28.

Jamil, Abdul. 2011. Pejabat Belum Gunakan Riset untuk Kebijakan. Diakses dari www.suarasilam.com.

Kasim, Musliar. 2011. Kebijakan Pendidikan Tak Berdasar Riset. Diakses dari www.kompas.com.

Miles, Matthew B dan Michael A. Huberman. 1992. Analisis Data Kualitatif. Jakarta: UI Press.

Moleong, Lexy J. 2000. Metode Penelitian Kualitatif. PT. Remaja Rosdakarya, Bandung.

Nugroho, Riant. 2011. Public Policy, Dinamika Kebijakan, Analisis Kebijakan, Manajemen Kebijakan. Jakarta : Elex Media Komputindo.

Pellini, Arnaldo and Serrat, Olivier. 2010. Enriching Policy With Research. Asian Development Bank (ADB).

Pestieau, Caroline. 2003. Evaluating Policy Research. Research Paper W/22 Work Network. Canadian Policy Research Networks.

Prayitno, Irwan dalam Haluan 7 April 2011. Banyak Kebijakan Tak BerdasarRiset. Diakses dari http://www.harianhaluan.com/index.php?option=co m_content\&view=article\&id=3361:banyakkebijakan-tak-berdasarkan-riset\&catid=1:haluanpadang\&Itemid $=70$.

Qodari. 2006. Riset Penting Dalam Mengambil Kebijakan Publik. Diakses dari http://www.kutaikartanegara.com/news.php?id=894

Rohmani dalam Republika (19 Agustus 2011) PKS: Pantas Pendidikan tidak Maju-Maju, Kebijakan tidak Berdasarkan Riset. Diakses dari http://www.republika.co.id/berita/pendidikan/berita -pendidikan/11/08/19/lq60p0-pks-pantaspendidikan-tidak-majumaju-kebijakan-tidakberdasarkan-riset

Royani, Mohammad Fathi. 2011. Memaknai Riset Dasar Sebagai Pijakan Awal Kebijakan. Diakses dari

http://www.ristek.go.id/index.php/module/News+N ews/id/8544/print. 
Smith, Bruce L. 2003. Public Policy and Public Participation Engaging Citizens and Community in the Development of Public Policy. Population and Public Health Branch. Atlantic Region. Canada.

Stine, Deborah D. 2009. Science and Technology Policymaking: A. Primer.Congressional Research Service (CRS) Report for Congress. Prepared for Members and Committees of Congress.

Sudharto.2012. Riset Harus Menjadi Pertimbangan Kebijakan. Diakses dari www.ikippgrismg.ac.id.

Susanto, Sri Nur Hari. 2000. Model Kebijakan Publik di Bidang BBM Dalam Kerangka Otonomi Daerah. Makalah dalam Sosialiasi dan Seminar Nasional Tentang Restrukturisasi Kebijakan Distribusi dan Pembiayaan BBM, Kerjasama Fakultas Hukum Universitas Diponegeoro dan Departemen Energi dan Sumber Daya Mineral.
Syahrasaddin. 2011. Kebijakan Harus Berdasarkan Riset Ilmu Pengetahuan Diakses dari www.metrojambi.com.

Wahab, Solichin Abdul. 2008. Pengantar Analisis Kebijakan Publik. Malang : UMM Press.

Wibawa, Samodra. 2011. Politik Perumusan Kebijakan Publik. Yogyakarta : Graha Ilmu.

Zamroni, Sunarji. 2008. Disorientasi Kebijakan Publik du Indonesia (Kasus Kenaikan Harga Gas Elpiji, Petramax, dan Rencana Kenaikan BBM). Institute of Research and Empowerment- Yogyakarta. IRE'S Insight. Working Paper/Zamroni/II/March/2008. 